\title{
The role of Engos in environmental litigation: a French case study
}

Citation for published version (APA):

Bentata, P., \& Faure, M. G. (2015). The role of Engos in environmental litigation: a French case study. Environmental Policy and Governance, 25(6), 459-473. https://doi.org/10.1002/eet.1682

Document status and date:

Published: 01/06/2015

DOI:

10.1002/eet.1682

Document Version:

Publisher's PDF, also known as Version of record

Document license:

Taverne

Please check the document version of this publication:

- A submitted manuscript is the version of the article upon submission and before peer-review. There can be important differences between the submitted version and the official published version of record.

People interested in the research are advised to contact the author for the final version of the publication, or visit the DOI to the publisher's website.

- The final author version and the galley proof are versions of the publication after peer review.

- The final published version features the final layout of the paper including the volume, issue and page numbers.

Link to publication

\footnotetext{
General rights rights.

- You may freely distribute the URL identifying the publication in the public portal. please follow below link for the End User Agreement:

www.umlib.nl/taverne-license

Take down policy

If you believe that this document breaches copyright please contact us at:

repository@maastrichtuniversity.nl

providing details and we will investigate your claim.
}

Copyright and moral rights for the publications made accessible in the public portal are retained by the authors and/or other copyright owners and it is a condition of accessing publications that users recognise and abide by the legal requirements associated with these

- Users may download and print one copy of any publication from the public portal for the purpose of private study or research.

- You may not further distribute the material or use it for any profit-making activity or commercial gain

If the publication is distributed under the terms of Article $25 \mathrm{fa}$ of the Dutch Copyright Act, indicated by the "Taverne" license above, 


\title{
The Role of Engos in Environmental Litigation: A French case study
}

\begin{abstract}
Pierre Bentata ${ }^{1 *}$ and Michael Faure ${ }^{2,3}$
${ }^{1}$ Center for Law and Economics Research (CRED), Paris II Panthéon-Assas University, Paris, France

${ }^{2}$ Maastricht European Institute of Transnational Legal Research (METRO), Maastricht University, Maastricht, The Netherlands

${ }^{3}$ Rotterdam Institute of Law and Economics (RILE), Erasmus School of Law, Rotterdam,

The Netherlands
\end{abstract}

\begin{abstract}
Both lawyers and economists are enthusiastic about the role of environmental nongovernmental organizations (ENGOs). However, when dealing with ENGOs, most academic studies focus only on their actions as interest/pressure groups and no systematic empirical research exists addressing the question of how ENCOs use environmental litigation and courts to fill their goals. In this article, we try to observe whether ENGOs have specific goals and specific strategies in trials. We do this on the basis of a unique database consisting of the entire set of environmental cases judged by the French Supreme Court during 1956-2010. We conclude that ENGOs' legal actions encourage compliance with regulation and help solve civil liability failures, especially causal uncertainty and victims' apathy. Finally, we observe that ENGOs act as latent interest groups that become active only under specific circumstances to ask for more stringent regulation. Copyright (c) 2015 John Wiley \& Sons, Ltd and ERP Environment
\end{abstract}

Received 22 November 2013; revised 28 November 2014; accepted 10 March 2015

Keywords: NGOs; environmental regulation; civil liability; interest groups; courts; legal strategies

\section{Introduction}

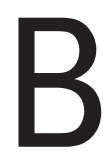

OTH LAWYERS AND ECONOMISTS ARE ENTHUSIASTIC ABOUT THE ROLE OF ENVIRONMENTAL NON-GOVERNMENTAL organizations (ENGOs) in ensuring compliance with environmental regulations. In the academic literature, it is commonly held that ENGOs may play several roles at different stages of the (regulatory) environmental protection process. According to Smith and Connelly (I999), ENGOs perform ten functions: 'informal, discrete lobbying, formal lobbying, collecting and sending letters or petitions from the public, producing scientific research and reports, taking legal action, organizing demonstrations and marches, staging media stunts, promoting consumer boycotts, engaging in non-violent direct action, engaging in violent direct action'. These functions can be grouped into three broad categories: 'Providing reporting and informing, Acting as pressure groups, Ensuring compliance with regulatory standards and duty of care'. It is more particularly the latter function of ENGOs that will be the focus of this contribution.

*Correspondence to: Pierre Bentata, Center for Law and Economics Research (CRED), Paris II Panthéon-Assas University, Paris, France. E-mail: pierre.bentata@u-paris2.fr 
When dealing with NGOs, most academic studies focus only on their actions as interest/pressure groups (Fredriksson, I997; Binder and Neumayer, 2005; Damania et al., 2005). In this context, NGOs aim at influencing officials and act as a counter-power to the lobbying activities of regulated industries (Stigler, I97I). Consequently, they help lower the risk of regulatory capture by industry, while political competition among pro-environment groups (ENGOs) and pro-industry groups (environmentally unfriendly facility owners) may facilitate the adoption of efficient regulation (Becker, I983). Finally, as far as litigation is concerned, the role of NGOs in the litigation process is twofold. First, they may represent a multitude of private interests. When an accident harms a large number of victims, victims can give their legal mandates to NGOs to sue the polluter for the entire damage instead of going individually to court. Consequently, only one trial will be necessary, and this may save on litigation costs. This would amount to a representative action whereby ENGOs represent the victims' interests in court. ${ }^{\text {I }}$ Second, they may help solve 'victims' rational apathy'. Indeed, when damages are widespread, the damage incurred by every victim is very small compared with the benefit of suing the polluter (Schäfer, 2000). In this case, ENGOs may sue the polluter for the whole damages by representing all the victims during the trial (i.e. a representative action). ${ }^{2}$ It could even be the case, especially with ecological damage, that individual victims cannot be identified, but that the damage is caused to collectively owned assets. ${ }^{3}$ In this case a so-called collective action can be brought. In a collective action an NGO sues on behalf of a collectivity without the need for individual victims to be known. ${ }^{4}$ Usually, in most legal systems, ENGOs do not sue to claim damages from the polluter (since the damage has to be personally suffered by the plaintiff), but they can bring an action for injunctive relief, e.g. requiring the polluter to stop polluting activities.

If ENGOs have specific purposes, they may have also specific strategies in trials. This is what we try to observe in this article. We do this on the basis of a database consisting of environmental cases that came before the Cour de Cassation in France. ${ }^{5}$

We first present a literature overview with respect to the role of ENGOs in the environmental liability system; then, we present the results of the ENGOs' legal actions and their efficiency, based on our dataset. Next, we provide a discussion of the results and conclude that ENGOs use environmental trials inter alia as a lobbying strategy, but also to remedy weaknesses in regulatory enforcement. The fifth section concludes.

\section{ENCOs Within the Environmental Liability System: Literature Review}

We first outline that most environmental control systems consist of a mix of environmental regulation and liability, which equally explains the differing roles of ENGOs; given this mix, we elaborate on the potential roles of ENGOs in environmental control, in general and in France specifically.

\section{A Joint Use of Environmental Regulation and Liability}

The French environmental legal system, as many other national systems, consists of a mix of regulation and civil liability. This combination appears to be more efficient than regulation or liability alone because both instruments, taken separately, suffer from important problems and their joint use helps to mitigate each other's failures. ${ }^{6}$ In the field of environmental accidents and pollution, civil liability alone is inefficient because polluters may often be 'judgment proof' (Shavell, I986), victims may suffer from 'rational apathy' (Schäfer, 2000) and causal links can seldom be established with absolute certainty when damages are either widespread or latent and/or the origin of harm

\footnotetext{
ISee further on representative action; also Keske et al. (2010). This is comparable to the role that consumer organizations would play when representing consumer interests in court.

${ }^{2} \mathrm{~A}$ representative action is a method to overcome the fact that there may not be any individual victim who suffered harm and hence would have incentives to sue; in a representative action group litigation is entrusted to an association endowed with funds, enabling it to bear the litigation costs (see Keske et al., 2010, p. 67).

${ }^{3}$ This is precisely how ecological damage is usually defined: as damage to goods that are not individually owned, as a result of which no individual victim exists of whom the property rights would have been violated. For further details see Liu (20I3).

${ }^{4}$ The difference between a representative action and a collective action is that in a representative action the ENGOs act to represent individual victims, whereas in a collective action the ENGO acts on behalf of the collectivity. See Keske et al., 20I0, pp. 60-67.

${ }^{5}$ The nature of the dataset will be further explained later.

${ }^{6}$ For the theoretical basis of this division of labour between liability and regulation see Shavell (I984).
} 
cannot be established when potential polluters use the same pollutants. Regulation intervenes before an accident occurs (ex ante) and therefore does not suffer from these problems (Rose-Ackerman, I991; Dewees et al., I996; De Geest and Dari-Mattiacci, 2003). However, to set efficient norms and standards, regulators need to assess the costs and benefits of care (Baumol and Oates, I988; Viscusi et al., I995). Consequently, they need to cooperate (Richardson et al., I982) with polluters and victims to obtain private information about their costs of care and their preferences. This cooperation process may then lead to 'regulatory capture' (Stigler, I97I). Hence, lowering the information constraint leads to more risks of capture. In this context, the introduction of civil liability enables compliant polluters to be held liable when it appears that they should have taken more care than asked for by regulators. Moreover, the threat of liability against regulators themselves may lower the risk of capture (Faure, 2007a).

This shows that the joint use of regulation and liability is desirable. Two other factors can also support such a joint use. First, it allows a clear division of tasks between the regulator and the judge. The former focuses on material aspects of care whereas the latter examines resource management. ${ }^{7}$ Second, smart inter-dependencies appear when regulation and civil liability are jointly used. When judges hold a compliant polluter liable, they provide information to regulators about deficiencies in their regulatory standards or the weakness of their implementation (Viscusi, 2006). Conversely, when regulators cooperate with polluters and audit them, they publish expertise and reports that may be used by victims and judges to solve causal uncertainty problems (Abraham, 2002). ${ }^{8}$

The literature therefore holds that joint use of regulation and civil liability is generally efficient, but that ENGOs can, moreover, contribute to effective environmental enforcement by taking action precisely where regulation may show weaknesses. ${ }^{9}$ In the next section we will show that our results indicate that ENGOs in France do indeed play a role supportive of regulation. First, we will sketch the different roles of ENGOs in general according to the literature and more particularly in the French legal system.

\section{Potential Roles of ENGOs in France}

In a previous study we showed that, since 2000 , these interactions between liability and regulation seem to have had a positive effect on French polluters' precaution, and especially on owners of the most regulated facilities (Bentata and Faure, 20I2). Nevertheless, the efficiency of the system depends on the victims' ability to sue polluters whenever damages occur (i.e., victims should not be apathetic). Consequently, as soon as damages are widespread or concern environmental resources without owners (pure ecological damage), victims' incentives to sue will be low and the overall efficiency of the system will be weak (Faure, 2007b). In this context, ENGOs may play an important role because they are entitled to request an injunction leading to restoration of the damaged environment or prevention of future harm (even though they do not own the damaged resource) and they can request victims' mandates to represent them before courts and to sue a polluter for the whole damage he caused to a group of victims or to society as a whole.

In the French legal system, ENGOs can intervene at two different levels in the management of environmental risks. First, they can be part of the regulatory process whereby regulators and the owners of hazardous facilities cooperate to define optimal safety standards. ENGOs can participate in environmental impact assessments and reveal potential victims' fears and preferences (Ogus, 2004). This role could be very desirable, because it may lower the risk of regulatory capture by the regulated industry and thus facilitate the adoption of optimal safety standards. Second, they are entitled to claim for recovery of costs incurred in the restoration or cleaning up of damaged environmental resources, ${ }^{\text {IO }}$ and can ask for compensation for environmental damages, as long as they suffered 'loss of enjoyment of life', ${ }^{\mathrm{II}}$ aesthetic damages ${ }^{\mathrm{I2}}$ or moral damages, ${ }^{\mathrm{I3}}$ no matter whether they actually own the resource. ${ }^{\mathrm{I}}$

\footnotetext{
${ }^{7}$ For an empirical analysis, see Bentata (2014).

${ }^{8}$ For a legal analysis of the American system see Abraham (2002), and for an empirical analysis of the French legal system see Bentata (2013).

${ }^{9}$ For a legal analysis of the joint use of tort law and regulation in France, more particularly in the framework of environmental protection, see Billet and Lichère (2007).

${ }^{10} \mathrm{CE} 8$ janvier I982, no I9959.

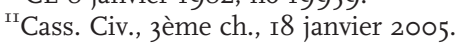

${ }^{12}$ Cass. Civ., 2ème ch. 29 novembre I995.

${ }^{13} \mathrm{CA}$. Aix en Provence, 25 juillet 2006; CA. Rennes, I8 avril 2006. 'Non-compliance with water quality standards is interpreted as moral damages against the reputation of an environmental NGO, even if no pollution/damages occurred.'

${ }^{\mathrm{I}} \mathrm{NGOs}$ do not need to own a resource to claim for compensation. Indeed they have to prove that, according to their legal statutes, they are dedicated to the protection of the environmental resource in question. Cass. Civ. Ière Ch., I6 novembre I982, no 8I-I5.550.
} 
According to economic theory, the fact that ENGOs can claim for compensation only after having cleaned up the polluted resource is efficient because it prevents opportunistic behavior and allows for a precise assessment of the whole damages. Note that this feature of French law is rather exceptional (Viney, 2006). ${ }^{15}$ In most legal systems, claims by ENGOs are limited in the case of ecological damage, i.e. damage to the un-owned environment (Liu, 20I3). Damage to e.g. seabirds in case of an oil spill cannot be claimed because they do not have an owner or another economically interested and potential real victim such as fishermen (Faure and Betlem, 2008).

Because they are part of the regulatory cooperative process and are also entitled to sue polluters, ENGOs might have an informational advantage during the trial (relative to other victims) to establish the negligence of a polluter or the causal link between the activities of a polluter and any environmental damage. Indeed, they have a stronger experience of how regulation works (via the cooperative process) and interact more often than other victims with regulated facilities, so they have a better knowledge of the organization and their management of environmental risks.

\section{NGOs Before the Courts: Stylized Facts and Methodology}

\section{Dataset}

To assess the role of ENGOs, we observe their actions before the French Supreme Court (Cour de Cassation) between I956 and 20I0. Using two French official legal search engines, ${ }^{16}$ which list all cases that have been before the Cour de Cassation since ${ }_{195} 6$, we first collected all the litigation concerning environmental damage judged by the French Supreme Court. ${ }^{17}$ We obtained 3206 different cases, and after selecting only litigation concerning environmental accidents, we were left with 6I5 relevant decisions. ${ }^{18}$ Among those 6I5 cases, 7 I concerned NGOs. ${ }^{19}$ For each case, we observed the following variables: year of the accident, plaintiff's identity (individual victim, NGOs, group of victims, regulatory agencies or state representatives), defendant's identity (small or medium-sized firm, large firms, environmentally unfriendly firms referred to as 'ICPE facilities', state-owned firms, state representatives, insurer of the polluter), damaged resources, presence of civil parties, ${ }^{20}$ presence of causal uncertainty, compliance with safety regulations (or not) and the legal basis invoked by the plaintiff. ${ }^{21}$

On this basis, all decisions in environmental damage cases judged by the French Supreme Court between ${ }^{2} 956$ and 2010 were classified, leading to various interesting results on the behavior of ENGOs before the courts. Some significant observations can be made on the basis of our dataset concerning the role played by ENGOs in environmental civil litigation in France. We first show that ENGOs mainly focus their efforts on those cases where regulatory enforcement may be weak or where other plaintiffs (ordinary victims) would not sue. We expand this point to show that the data indicate that ENGOs focus on those cases where private civil litigation by victims may be particularly weak. The dataset hence provides some insights into the (implicit) method of case selection by ENGOs. ${ }^{22}$

\footnotetext{
${ }^{15}$ In general, until 2005 standing was much more easily granted in France than in other legal systems in Europe. In other European legal systems standing for ENGOs was only broadened after the implementation of the Aarhus Convention (more particularly Art. 9(3)) and the way in which this convention was interpreted in recent case law of the Court of Justice of the European Union (see Backes et al., 20I4). As we will indicate below, the situation also changed in France in 2005 when the role of ENGOs was severely limited.

${ }^{16}$ Lamyline and Dalloz, www.lamyline.fr; www.dalloz.fr

${ }^{17}$ To collect the entire set of relevant litigation, we used the following keywords: pollution, ecological damage, environmental damage, ecological loss, environmental loss, environmental risk, ICPE, natural catastrophe, risk prevention, precautionary principle, trouble de voisinage (neighborhood dispute).

${ }^{18}$ Most of the 3206 cases were not directly related to environmental accidents, although they contained one or more keywords. For instance, more than 300 cases were concerned with environmental taxation, more than a thousand cases were concerned with 'neighborhood disputes' where pollution was not an issue and about a thousand cases concerned litigation before lower courts. Although these latter cases may provide information (and increase the size of our dataset), we could not use them because they represent a very small fraction of the litigation that came before lower courts and may not be representative of lower courts' decisions.

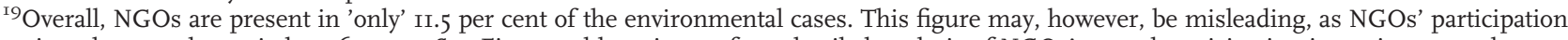
varies a lot over the period I956-20IO. See Fig. 2 and later in text for a detailed analysis of NGOs' annual participation in environmental cases. ${ }^{2 \circ} \mathrm{Civil}$ parties are the victims of a crime that, according to French criminal procedure, can present themselves as 'parties civiles' and claim compensation from the wrongdoer in the criminal court.

${ }^{21}$ Legal grounds are detailed later.

${ }^{22}$ Our dataset is only based on the environmental cases brought by ENGOs before the Supreme Court of France. ENGOs may, however, also bring administrative cases before administrative courts and the Supreme Administrative Court (the Conseil d'Etat). These have not been included in our dataset. Hence, our analysis regarding the role of ENGOs in civil liability litigation cannot be extended to the role of these organizations in administrative litigation.
} 


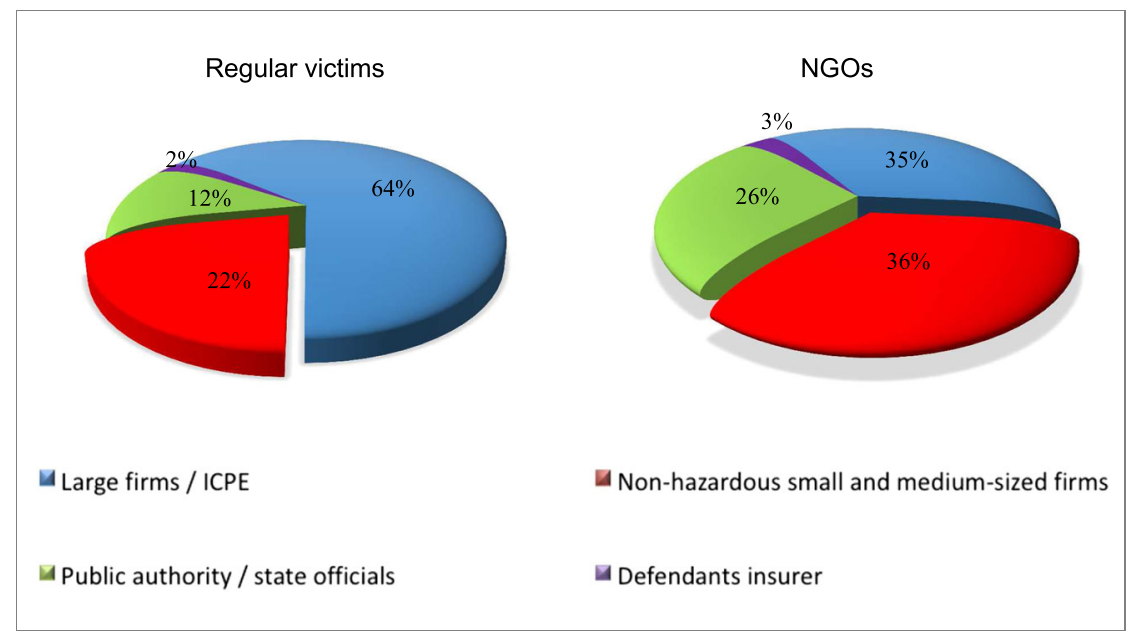

Figure 1. Defendant's identity given plaintiff's identity

\section{A Complement to Regulation: Stimulating Prevention in Weakly Regulated Facilities}

ENGOs' legal actions are very different from other victims' legal actions. In contrast to individual victims, they do not focus on the most regulated firms. Indeed, whereas the most environmentally hazardous firms (commonly referred to as ICPE facilities $)^{23}$ are present in 64 per cent of suits brought by individual victims, they are present in only 35 per cent of the suits brought by ENGOs (see Fig. I).

It seems that ENGOs are just as likely to sue ICPE facilities, non-hazardous facilities ( 36 per cent) and state-owned companies or state officials ( 26 per cent). Indeed, Fig. I shows that 'normal' victims are more likely to sue ICPE facilities (in $64 \%$ of cases), whereas ENGOs divide their efforts over the various defendants. Thus, ENGOs may act as a complement to regulation, since they often sue weakly regulated facilities that are not monitored by regulators because of budget constraints. In fact, due to the regulators' budget constraint, even the most regulated firms face a very low probability of being audited: according to our own calculation, only 42 per cent of the 50 000 ICPE facilities subject to authorization and 2 per cent of the 450000 other ICPE facilities are audited, for at least one hour on an annual basis, by the II7I ICPE inspectors. Consequently, these ICPE facilities and other non-hazardous facilities only face a very low probability of being audited, which may reduce their incentives to take preventive measures.

How should one, given these data, view ENGO activity, more particularly their focus on non-hazardous firms? According to the cases before the Cour de Cassation, approximately one-third of environmental accidents are caused by these non-hazardous small and medium sized firms. ${ }^{24}$ Given budget constraints, regulatory authorities do not strongly focus on controlling these non-hazardous small and medium sized firms. The focus of ENGOs on those types of non-hazardous facility could hence be considered as an instrument to provide operators of non-hazardous facilities with additional incentives to invest in prevention.

It seems that only ENGOs can be considered as a credible threat for the owners of non-hazardous facilities, because looking for evidence of environmental damage and negligent behavior is a costly activity that individuals can often not afford, especially if damages are widespread or concern an un-owned natural resource. Of course, we do not claim that it is necessarily a deliberate strategy of (French) ENGOs to focus on non-hazardous facilities, thus playing a complementary role to regulators and other victims.

However, ENGOs' activism in this respect seems at least to show some effectiveness. Indeed, our statistical results show that there is a correlation between ENGOs' legal activity and the proportion of defendants who complied with environmental/safety regulation (see Fig. 2).

\footnotetext{
${ }^{23}$ Since 1976 , the most environmentally endangering facilities are subject to the Classified Facilities Act of I9 July I976. Among these ICPE facilities, we find the most risky and most regulated facilities.

${ }^{24}$ Of course, this should be nuanced in the sense that there may be a strong bias of the type and number and cases that come to the French Cour de Cassation. However, if there were any bias, it is more likely that more of the damage cases involving large ICPE firms would go to the Cour de Cassation.
} 


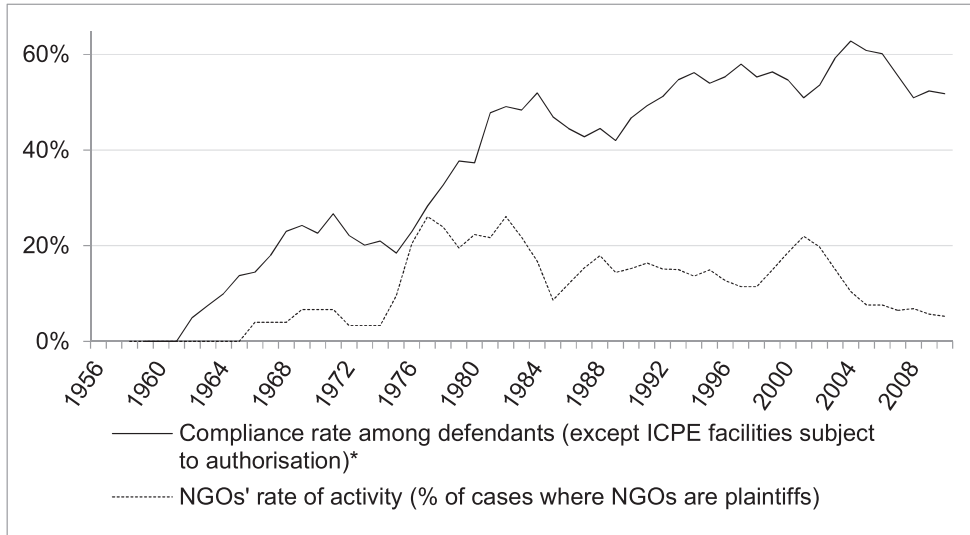

Figure 2. NGOs' activity and defendants' compliance rate (percentage of total cases)

From our database, we observe for each year the number of cases where the defendant did comply with regulation, out of the total amount of cases judged during that year. In the same vein, we observe for each year the number of cases where the plaintiff was an NGO as a percentage of the cases judged during that year. Of course, Fig. 2 represents aggregate numbers for all defendants and all plaintiffs. ${ }^{25}$ At this aggregate level there seems to be a correlation between ENGO activity and the compliance with regulations by the defendants.

Indeed, the evolution of the defendants' compliance rates follows the evolution of ENGOs' legal activity, with a lag of one year: from I974 to I977 ENGOs' activity sharply increased (they were present in less than 5 per cent of the cases in I974 and in almost 25 per cent in I977), and from I975 to I978 the compliance rate among defendants increased from less than 20 per cent to almost 40 per cent (the number of defendants who actually complied with regulation almost doubled in three years). Thus, ENGOs' willingness to (also) sue weakly regulated firms seems to encourage compliance with regulation. This finding might (partly) explain a phenomenon that is referred to in the literature as the 'Harrington Paradox'. This refers to the fact that in some cases high levels of (costly) compliance with regulation can be observed even when the probability of being audited is low. ${ }^{26}$ Different explanations for this phenomenon have been presented. Compliance may be driven inter alia by lacking information (on e.g. the low probability of detection) but also by culture and social norms. ${ }^{27}$ Our data seem to indicate one additional explanation: ENGO activity and the resulting threat of being held liable by courts could drive firms towards compliance even when the probability of enforcement by regulatory authorities is low.

\section{Case Selection by ENGOs}

The point we made in the previous section, namely that ENGOs apparently implicitly focus their efforts on cases either where regulatory enforcement may be weak or where other victims may have less possibility to sue, can also be illustrated by a more careful analysis of the specific cases in which ENGO activity in courts is higher. ENGOs seem to focus strongly on ecological damage and also use different legal bases for claims than other victims. Moreover, ENGOs seem to be more successful in the case of causal uncertainty than other victims.

\section{ENGOs Focus on 'Ecological' Damage}

Another important difference between ENGOs and other victims lies in the characteristics of their legal actions. Overall, ENGOs are the plaintiffs in I2 per cent of the cases. They appear to focus mostly on two issues: water pollution and imminent risk ${ }^{28}$ (see Table I). Indeed, 69 per cent of the suits brought by ENGOs concern water pollution (whereas

\footnotetext{
${ }^{25}$ Hence, we do not claim that in our particular case, where the defendant complied, it was directly linked to the fact that the plaintiff was an ENGO.

${ }^{26}$ For a detailed explanation of the 'Harrington Paradox', see Harrington (I988). See also Harford and Harrington (I99I) and Nowell and Shogren (I99I).

${ }^{27}$ For the role of social norms in furthering compliance with legislation see Faure and Escresa (20II).

${ }^{28}$ This notion of 'imminent risk' (in French danger imminent) refers to a situation where there is an immediate threat of damage if no specific action is rapidly taken.
} 


\begin{tabular}{lcc}
\hline & Regular victims & NGOs \\
\hline Water & 33 & 69 \\
Noise & 22 & 1 \\
Soil & 15 & 1 \\
Air & 13 & 2 \\
Imminent risk & 9 & 21 \\
Aesthetic & 5 & 1 \\
Sea & 3 & 5 \\
\hline
\end{tabular}

Table 1. Damaged resource at stake: regular victims versus NGOs (percentage of all cases)

water pollution is an issue in only 33 per cent of the cases brought by other victims) and 2I per cent of the cases brought by ENGOs concern the risk of occurrence of an accident (whereas imminent risk is invoked in only 9 per cent of the cases brought by other victims).

ENGOs rarely sue polluters when noise or land pollution is at stake (I per cent of the cases, whereas noise and land pollution are at stake in respectively 22 per cent and I5 per cent of the legal actions brought by other victims). This difference might be due to the fact that noise generally concerns only a few people and the responsible polluter is often known with certainty. Thus the causal link can easily be established and the scope of damages can easily be assessed. Consequently, civil liability can efficiently cope with these situations. In these cases (noise and land pollution) the action by ENGOs may therefore not be necessary to counter the widespread nature of the damage and/or the rational apathy on the side of the victim.

On the other hand, cases concerning water pollution and imminent risks are more complex because (i) the scope of damages cannot be easily assessed: water pollution implies loss of biodiversity, and imminent risk means that damages have not occurred yet; (ii) the resource is often not owned by a specific victim or cannot easily be protected (e.g. pollution of rivers) and (iii) the causal link between any specific damage and a polluter cannot be established with absolute certainty (e.g., many potential polluters use the water from the same river). Thus, the chance of success for individual victims may be low when water pollution or the risk of accidents is at stake and this may lead to victims' apathy. This is often considered as a serious failure of French civil liability, since water pollution represents 80 per cent of French environmental accidents and damages from water pollution may result in losses for a large number of victims and also for the entire eco-system (Quirion, I999).

Hence, we can conclude that ENGOs focus on the most complex cases. By primarily bringing suits for water pollution, they concentrate their actions on those cases where other victims will face high legal costs, because they do not suffer from immediate losses on their property (imminent risks or un-owned resources), and high causal uncertainty (water pollution), and will therefore have low incentives to sue. Indeed, as mentioned above, ENGOs often claim for 'loss of enjoyment of life', moral damages, ${ }^{29}$ aesthetic damages as direct damages to their reputation, ${ }^{30}$ or pure economic losses due to losses of biodiversity. ${ }^{3 \mathrm{I}}$ These claims cannot be made by individual victims because they do not concern a personal and direct damage (Carbonnier, 2004). ${ }^{32}$ Hence, because of their specific legal status, ENGOs, accredited ${ }^{33}$ or not, ${ }^{34}$ are the only plaintiffs who can claim for compensation of ecological damages ${ }^{35}$ (i.e. damages to the environment itself). As a result, ENGOs act as a substitute for individual victims, when victims may be apathetic and/or when the assessment of damages may be a serious issue. ${ }^{36}$

\footnotetext{
${ }^{29}$ The moral damages of an ENGO are defined in a very broad sense: the death of an endangered bird of prey gives right to compensation for moral damage, Cass. Civ. ière Ch., I6 novembre I982, no 8I-I5.550.

${ }^{3 \circ} \mathrm{CA}$. Aix en Provence, 25 juillet 2006, CA. Rennes, 18 avril 2006.

${ }^{3 \mathrm{I}} \mathrm{CA}$. Rennes, I9 décembre I997; Revue Juridique de l'Environnement I994, p. 623. The pollution of a river has been considered as a pure economic loss for an ENGO dedicated to its protection, and the court awarded compensation of I franc multiplied by the surface of the river $\left(34400 \mathrm{~m}^{2}\right)$.

${ }^{32}$ Nevertheless, this could change within the next few months, as the Ministère de l'Ecologie will introduce the notion of 'pure ecological damage' in the Civil Code in 20I4.

${ }^{33}$ Cass. Civ., 2ème Ch., 7 décembre 2006, no 05-20.297.

${ }^{34}$ Cass. Civ., 2ème Ch., 5 octobre 2006 , no 05 -17.602.

35TGI. Paris, I6 janvier 2008. See also Boutonnet (20I0), and for a comparative approach see Liu (20I3).

${ }^{36}$ Décret II février 2002, no 2002-I96. Damage assessment is easier for ENGOs because they have to clean up an environmental resource before claiming for compensation. Thus they can provide evidence of the real costs of environmental damages.
} 
Different Reasons to Sue

Plaintiffs have different reasons for suing a defendant. In our dataset we have differentiated these reasons as follows ${ }^{37}$ :

(i) human error or negligence;

(ii) non-compliance with regulation;

(iii) the duty to compensate;

(iv) uncertainty about the consequences of an accident and

(v) neighborhood disputes.

(vi) Human error or negligence is invoked by plaintiffs when they claim that an accident occurred because of careless behavior or organization within the firm. In this case, victims refer to Art. 1382 of the Civil Code and aim to show that the defendant broke a general duty of care. Consequently, when victims invoke this legal ground, they perceive liability as a way to deter the risk-taker from taking risks.

(vii) Non-compliance is invoked when victims claim that damages occurred because the defendant did not comply with safety regulations. Again, invoking non-compliance reveals the deterring effect of liability.

(viii) The duty to compensate is invoked when victims claim that they are entitled to be compensated for damages to their person or property. In this case, they refer to Art. 1384 『I of the Civil Code or to case law $^{38}$ to claim that the defendant, as a custodian of the object that caused the accident, is liable for the damage it caused, no matter whether he or she acted negligently or not. When victims invoke this legal ground, they perceive liability as a financial instrument to obtain compensation for any loss they suffered. ${ }^{39}$

(ix) Uncertainty about the consequences is invoked when victims claim that they are facing an imminent risk or that damages in the case of an accident may be catastrophic. In this case, they refer to the precautionary and/or prevention principles to ask for more stringent regulation and for more information about the way regulators designed and enforced safety norms and standards. When victims invoke this legal ground, they reveal their distrust of the current regulation.

(x) Neighborhood disputes are invoked when parties disagree on the definition of what is a 'reasonable level of nuisance'. Victims explicitly refer to the concept of 'troubles de voisinage'. When parties invoke this legal ground, they perceive a lawsuit to the court as a way to determine whether the polluting activity is socially acceptable or not. ${ }^{\circ}$

The dataset provides the picture in Table 2 .

What do these figures teach us?

NGOs and individual victims do not engage in civil lawsuits for the same reasons. Indeed, the fact that they do not invoke the same legal grounds in the same proportions reflects the different natures of their legal actions, i.e. they are not concerned with the same kind of accident and damage. According to our figures, victims invoke neighborhood disputes twice as often as ENGOs, and cases where such legal grounds can be invoked are often simple ones concerning only two persons and with small levels of pollution and damage. Thus, the fact that ENGOs do not often invoke this legal ground may provide evidence that they focus on more complex cases, where damages are widespread or concern a large number of people. In the same vein, the fact that ENGOs invoke 'uncertainty about the consequences' only in Io per cent of the cases whereas individual victims invoke it in I5 per cent of the cases reveals that ENGOs are more likely to go to court once an accident has actually occurred. Finally, full compensation of environmental damages appears to be a major goal of ENGOs. Indeed, the duty to compensate is invoked, as a

\footnotetext{
${ }^{37}$ These are five categories that we have used to classify the cases in our dataset. They are not necessarily the legal grounds on which the plaintiffs based their suit, but provide information on the victim's perception of the role of civil liability: do plaintiffs go to court to be compensated, mainly to punish the wrongdoer or to provide him with incentives to take care or to reveal private information about the risks?

${ }^{38}$ Cass. Civ. 2ème Ch., 28 octobre I954, Juris-Classeur I955. II. 8765. This is a strict liability rule. For details see Prieur, 20II, pp. I058-IO59.

${ }^{39}$ In our dataset, when plaintiffs invoke this legal ground, they mostly refer to the first goal of civil liability, that is to say 'to fully and exactly compensate victims for a prejudice caused by the defendant'. In French, this principle is called 'principe de réparation intégrale' and has been confirmed by the jurisprudence, also often invoked by victims in our dataset: 'Le propre de la responsabilité civile est de rétablir aussi exactement que possible l'équilibre détruit par le dommage, et de replacer la victime dans la situation où elle se serait trouvée si l'acte dommageable ne s'était produit'. See Cass. Civ zème Ch., I avril I963, Juris-Classeur I963. II. I3408, note ESMEIN. For a detailed analysis of the 'principe de réparation intégrale' see Viney and Jourdain (200I).

${ }^{4}$ From an economic perspective, courts help to solve the problem of 'negative externality' by determining whether this externality is Pareto relevant (i.e. can be lowered at reasonable costs) or not. See Coase (I960) and Buchanan and Stubblebine (I962).
} 


\begin{tabular}{lcc}
\hline & Regular victims & NGOs \\
\hline (i) Human error/negligence (Art. 1382 CC) & 30 & 28 \\
(ii) Non-compliance & 21 & 23 \\
(iii) Duty to compensate (Art. 1384(1) CC) & 19 & 30 \\
(iv) Uncertainty about the consequences of the accident & 15 & 10 \\
(v) Neighborhood disputes & 15 & 9 \\
\hline
\end{tabular}

Table 2. Legal grounds invoked by regular victims and NGOs (percentage of all cases)

a Legal grounds represent the reason invoked by the plaintiff, the defendant or both when they appeal to the French Supreme Court. For instance, human error/negligence is invoked when the question is whether the plaintiff was negligent; duty to compensate is invoked when parties disagree over the amounts of compensation awarded by the lower court.

\begin{tabular}{lrr}
\hline & Regular victims & NGOs \\
\hline Causal uncertainty (percentage of all cases) & 40 & 52 \\
Rate of success (percentage of the cases where causal uncertainty is an issue) & 21 & 30 \\
Use of external expertise (percentage) & 42 & 79 \\
\hline
\end{tabular}

Table 3. Regular victims' and NGOs' rates of success under causal uncertainty

legal ground, in 30 per cent of the cases brought by ENGOs (whereas it is invoked in i9 per cent of the cases brought by other victims).

How can we interpret these differences between ENGOs and other victims? Overall, the statistical results show that individual victims are more likely to sue a polluter for a breach of a duty of care (either non-compliance with regulatory standards or negligent behavior), whereas ENGOs are more concerned with the amount of compensation. Thus, it seems that individual victims perceive civil liability as a way to deter potential polluters whereas ENGOs perceive civil liability as a means to force polluters to fully compensate environmental harm. They do not use the same legal ground to bring legal action, and this may reveal a different perception of the role of civil liability. Victims tend to go to court to claim that the polluter took too much risk - and refer most of the time to Art. I3 82 of the Civil Code or to administrative laws related to environmental regulation - whereas ENGOs (mostly) go to court to be awarded financial compensation - and refer to Art. I384 『I of the Civil Code.

The focus of individual victims on showing negligence or non-compliance may be explained by the fact that their primary concern is compliance by the polluter with regulatory standards in order to improve the quality of life of the victim. The focus of ENGOs on compensation may (to some extent) also be related to the financing strategies of the ENGOs. After all, the proceeds of the court cases can and will also be used by ENGOs to finance other activities.

\section{ENGOs and Causal Uncertainty}

Another important observation can be made from our database: ENGOs are more successful than other victims in the presence of causal uncertainty (Table 3). With causal uncertainty we refer to a situation where the causal relationship between a particular act (e.g. an emission) and the damage (e.g. personal injury) is not clear. Causal uncertainty may especially be a problem when there are either multiple victims and/or multiple polluters (Ben-Shahar, 2009). Table 3 shows the rate of success of the different types of plaintiff in a situation of causal uncertainty.

As the table shows, causation is uncertain in 52 per cent of the cases brought by ENGOs (40 per cent of the cases for other victims), and still they win 30 per cent of these cases, whereas other victims win 2I per cent of the cases where causation is uncertain. Hence, ordinary victims only win 2I per cent of the 40 per cent of cases in which causal uncertainty is an issue, whereas ENGOs win 30 per cent of the 52 per cent of cases in which there is causal uncertainty. At first sight, ENGOs' greater efficiency in establishing causation might be surprising, since they focus on the most complex cases, where causation may be difficult to prove (water pollution). ${ }^{4 \mathrm{I}}$ Their ability to prove the

\footnotetext{
${ }^{4}$ The relative success of the ENGOs in these complex cases may also be due to the fact that they (e.g. water pollution) often attract great attention from the media. This can in turn influence courts and thus aid ENGOs in overcoming the proof problem.
} 
causal link between environmental damages and a polluter is probably related to their scientific expertise: they use scientific reports in 79 per cent of the cases whereas other victims provide scientific evidence in only 42 per cent of the cases. This difference may be explained by the greater experience of ENGOs in environmental litigation. They may have better information about the legal procedures, which may increase their chances of success (Deffains and Langlais, 20I2). These findings seem to confirm that ENGOs bring more legal actions when causation is uncertain and that they are still more successful than other victims in winning those cases.

From these results, it seems that, as far as civil liability is concerned, ENGOs focus on very specific cases where causal uncertainty and damages to un-owned resources would prevent individual victims from suing the polluter. Thus, ENGOs seem to be aware of the traditional failures of environmental civil liability and aim at mitigating them. Once more, this shows that ENGOs seem, at least implicitly, to be aware of the important supplementary function they fulfil in suing precisely in those cases where individual victims may be in a particularly disadvantageous position or lack the incentive to sue (due to uncertainty over causation).

\section{Discussion}

We will now analyze the results of the dataset presented in the previous section and argue that the actions of ENGOs in France to supplement weaknesses in regulatory enforcement and civil liability could be considered as a lobbying strategy, leading more particularly to a demand for regulation since the ENGOs can be considered as a (latent) interest group.

\section{A Demand for Regulation}

As compared with other victims, ENGOs apparently follow a specific strategy when going to court: they bring suits only in the most dangerous situations (water pollution or imminent risks) and most of time sue weakly regulated firms that are rarely audited. This might be seen as a way to reveal regulatory failures. ENGOs may go to court in order to inform regulators about the gap that exists between safety standards and victims' preferences. Consequently, ENGOs specific legal actions may be interpreted as an input in the regulatory process of designing optimal standards of care (Dari-Mattiacci et al., 20II). Indeed, ENGOs' legal actions are very homogeneous. Then, if judges award them compensation (i.e. if ENGOs win their trials), they provide regulators with relevant information about the fact that a particular category of facilities is likely to cause specific environmental damages. Regulators may use the results of these cases (judicial decisions) to assess whether safety standards are well defined and whether monitoring is efficient.

For instance, the increase of environmental litigation concerning an imminent risk of accident reveals that civil society does not feel comfortable with the current situation, which means that it needs either more information about the efficiency of current standards or more stringent regulation or enforcement. This interpretation of ENGOs' legal strategy seems relevant, since ENGOs almost always base their claim on the Barnier Law, which introduced the precautionary principle into the field of environmental risks. ${ }^{42}$ From an economic perspective, when ENGOs claim compensation for pure ecological damages or for more regulation due to an imminent risk of environmental accident, they reveal the existence of a relevant externality (Buchanan and Stubblebine, I962) that cannot be revealed by unorganized individual victims because of the legal costs of going to court and the low probability of winning the case. In other words, whenever total damages are worth going to court, but individual damages are not, ENGOs act as a substitute for individual victims, and the growing number of similar cases (based upon the same legal ground and concerning the same environmental problem) reveals the social demand for more or better regulation. ${ }^{43}$ Hence, ENGOs reveal the need for adapting safety standards when costs and benefits of regulation change. This role may be very useful since regulatory lack of flexibility (due to informational constraint) is often cited as a major source of regulatory inefficiency (Viscusi et al., I995). We can then easily understand why

\footnotetext{
${ }^{42}$ Loi 2 février I995, no 95-IOI, on the strengthening of environmental protection. This precautionary principle now has legal force in France and is also considered as a source of civil liability in litigation between private persons (see Prieur, 20II).

${ }^{43}$ ENGOs reveal the evolution of social preferences vis-à-vis environmental risks and damages. Consequently, they provide very useful information to the regulator as far as the design of optimal standards is concerned. Indeed, the optimal level of care is the level at which the marginal abatement cost is equal to the marginal benefit of risk reduction, and marginal benefits depend on victims' preferences. See Ogus (2004).
} 


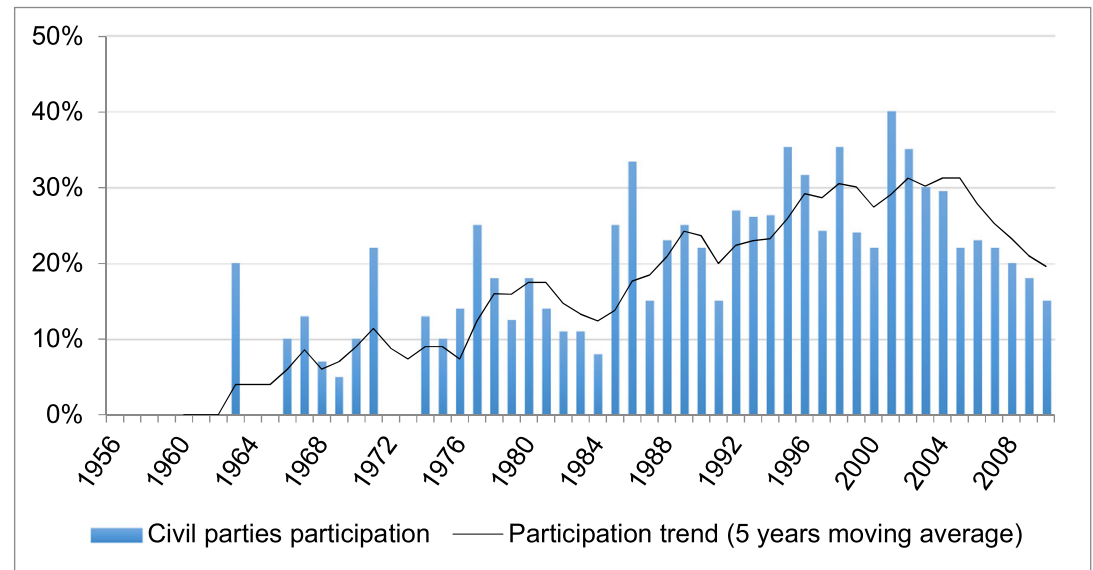

Figure 3. Collective actions in civil environmental litigation (as a proportion of all cases)

ENGOs focus on weakly regulated facilities: they inform regulators about the need to further differentiate safety standards among these facilities. These results therefore show that ENGOs on the one hand stimulate compliance with regulation and on the other hand intervene especially when regulatory enforcement is weak. This corresponds to the theoretical literature pointing to the need for a joint use of regulation and liability rules (see supra).

\section{A (Latent) Interest Group}

From the above statistical results, it seems that ENGOs act as an interest group. Before exploring their lobbying strategies towards regulators and judges, it seems important to emphasize that their potential influence comes from their ability to bring collective actions.

ENGOs as a Driver for Collective Action

ENGOs inform people by publishing reports on their activities and aim at mobilizing victims by requesting their mandates to represent them before courts. As indicated in the previous section, our results show that ENGOs are more likely to bring representative lawsuits ${ }^{44}$ : they represent individual victims in 36 per cent of the cases, whereas collective actions represent only 24 per cent of all cases. ${ }^{45}$ This specificity lies in the fact that French victims of environmental accidents prefer giving their legal mandates to ENGOs (rather than to state officials or to a representative from a group of victims) because they are already organized (Boré, 20Io). ENGOs may benefit from expertise with environmental litigation and they are only motivated by the protection of the environment (Viger, 2000). Consequently, it is not surprising that the number of collective action lawsuits is highly correlated to the legal activity of ENGOs (Fig. 3).

The trend of collective actions (as part of the total case load) exceeded Io per cent for the first time in I976 and reached I8 per cent in I982. Then, the trend increased slightly and reached a peak (more than 30 per cent) between 2000 and 2004 . From Fig. 2, we can observe that during these two periods ENGOs' activity was at its highest level (they were present in about 20 per cent of the cases). Hence, French collective actions seem to be mostly driven by ENGOs. From an economic perspective, collective action is an appropriate remedy, especially in cases of widespread damage (Sintez, 20II) where the loss is scattered over a wide number of victims, resulting in victims' apathy (Schäfer, 2000). ENGOs can, in the environmental arena, therefore play a positive role via collective actions (Deffains et al., 2008), and use these collective actions as a means to inform people and gain media coverage.

\footnotetext{
${ }^{44}$ In French law, victims who have suffered the same kind of damage can group their action or give their mandates to an NGO that will claim compensation on behalf of the group. In French criminal law, victims are also entitled to give their mandates to the public prosecutor. However, victims of criminal offenses can choose to sue the defendant before the civil court and be represented by an NGO. See Viger (2000).

${ }^{45} \mathrm{Among}$ this 24 per cent, two-thirds concern neighborhood disputes (troubles de voisinage), i.e. cases where damages are low and causation is obvious.
} 
Indeed, as indicated in previous sections, ENGOs focus on cases involving a large number of persons and potentially dramatic damages. These cases are obviously more covered by the media. Hence, ENGOs may use collective actions in cases of environmental catastrophes to increase their popularity and eventually their influence over policy-makers.

However, the number of environmental collective actions has sharply decreased since 2005, and at the same time ENGOs' rate of activity fell below 5 per cent (for the first time since 1974), whereas between 2000 and 2004 ENGOs were always present in more than I5 per cent of the cases. Moreover, ENGOs' rate of success fell from 48 per cent before 2005 to I2.5 per cent after 2005. The reason for this dramatic evolution lies in the fact that the French Code de l'Environnement, enacted in 2005, severely limits the role of ENGOs. Indeed, the burdensome new procedure forbids ENGOs directly requesting victims' legal mandates to bring a lawsuit on their behalf. ${ }^{46}$ ENGOs can bring a collective action lawsuit only if the victims give them their mandates (Boré, 20I0). In this sense, the French legislator has changed the collective action to a representative action where an ENGO files a suit on behalf of the victims. ${ }^{47}$ Consequently, ENGOs have to wait for victims' requests and the cost of bringing a collective action immediately increases, since victims are not always informed either about the existence of the ENGO or about the scope of damage. Moreover, this requirement of a request by a victim may be quite problematic, especially in the case of so-called victimless pollution. This refers to the situation where the pollution is so widespread that no individual victim has an incentive to bring a suit or to report the damage to an ENGO. As a result, victims' apathy remains a serious issue and ENGOs cannot act as an efficient substitute for individual victims anymore. This new legal burden on ENGOs may have an even more dramatic impact for the entire legal system, as ENGOs act as a pro-environment lobby.

\section{ENGOs as Pro-Environment Interest Groups}

From our results, we can conclude that ENGOs act as (latent) interest groups (Olson, I994): they aim at influencing legislators (both regulators and judges) only when a major accident occurs or may occur with a high probability. In so doing, they reveal the failures of the legal system. Indeed, from Figs. 2 and 3, we observe that ENGOs' activity level increases at very specific moments: they brought lawsuits for the first time in I966, a first peak appears between 1976 and 1983 and a second one appears between 1999 and 2003. Only during these two periods, ENGOs are present in more than 20 per cent of all environmental cases. By comparing these periods with the year of occurrence of major environmental accidents in France, we can observe that ENGOs are more prone to bring lawsuits when an environmental accident has occurred and during the two following years. Indeed, the first French industrial and environmental catastrophe occurred in I966 (Feyzin refinery explosion). Then, between I976 and I980, three major oil spills damaged the French Coasts (Boehlen in 1976, Amoco Cadiz in I978 and Tanio in I980). Finally, the third period matches with the Erika (2000) and the Prestige (2002) oil spills and the AZF-Toulouse explosion (200I). Thus, it seems that ENGOs use these major environmental accidents as a means to influence both regulators and judges. When a major accident occurs, the regulator is under particular pressure from both the government and civil society, and consequently he or she is more likely to impose new and more stringent standards (Keenan and Rubin, I988). In France, the most important environmental rules were set up in I976 (ICPE Act ${ }^{48}$ ), in 2000 (transposition of the Seveso II European Directive ${ }^{49}$ ) and in 2003 (Bachelot Act ${ }^{50}$ ), i.e. at the time when major environmental accidents occurred. Although it might be seen as a regulatory capture by pro-environment lobbies (Faure and Van den Bergh, I990), in the domain of environmental accidents the ENGOs strategy could be desirable because the risk of capture by unorganized victims of widespread damages seems to be far lower than the risk of capture by the regulated industry (Olson, 1994; Rachlinski, I998; Kuran and Sunstein, I999).

Finally, from an interest group perspective, ENGOs' legal actions may also influence judges' decisions (Keenan and Rubin, I988). Our results show that the ENGOs' rate of success is higher during periods of environmental catastrophes ( 53 per cent, whereas overall the rate of success is 48 per cent). Thus it seems that judges, like regulators, are more severe when an environmental accident has recently occurred.

\footnotetext{
${ }^{47}$ Representative actions are considered less favorable in law and economics literature, compared with collective actions (see Keske et al., 20Io, pp. 67-72).

${ }^{48}$ Loi i9 juillet I976, no 76-663, on classified facilities for the protection of the environment.

${ }^{49}$ Arrêté Io mai 2000 , on the prevention of major accidents implying hazardous and toxic products.

${ }^{50}$ Loi 30 juillet 2003 , no $2003-699$, on the prevention of technological and natural risks.
} 
It is of course one thing to notice that ENGOs' legal actions and their rate of success affect judges and regulators; it is quite another to evaluate whether this is, at the policy level, a desirable role. On the one hand, it has already been repeatedly mentioned that ENGOs can undoubtedly play an important role in the regulatory process as a shadow interest group, channeling the sentiments of civil society concerning particular environmental issues. On the other hand, the mere fact that legislation typically emerges and ENGOs' chances of success increase during periods of environmental catastrophes can of course not only be explained as instruments of effective environmental policy, created in the public interest. One therefore has to be careful in drawing normative conclusions from the relative success of ENGOs in the case of France at the policy level. It would more particularly be wrong to conclude on whether the legislation and case law that resulted from strong ENGO activity after particular disasters is effective or not. We argued earlier that both at a regulatory level and in litigation ENGOs can play a positive role in remedying weaknesses in regulation and in the civil liability regime. However, the danger of a regulatory action as a result of disasters is that, as we just indicated, that regulation can often be inefficient as a result of the availability heuristic. Whether the particular regulations that were consequently promulgated in France following a specific disaster can thus be considered as optimal is yet another issue that is beyond the scope of this study. Moreover, the mere fact that we found that ENGOs act more specifically where regulatory agencies have more difficulties may as such provide some indication on the practical attitude of ENGOs. It is, however, quite another issue to argue that this collaboration would be optimal or that it would actually improve compliance by firms. Our dataset does not allow us to reach these conclusions.

\section{Conclusions}

The positive role that ENGOs could play in environmental policy has often been stressed as far as improving the quality of environmental regulation is concerned. ENGOs can provide an important counter-balancing power against industry lobbying (Becker, I983). As far as the political process is concerned, empirical evidence has also been provided for the fact that the strength of ENGOs can achieve lower pollution levels and increase environmental quality (Binder and Neumayer, 2005). Theoretically, a similar argument has been made for a role for ENGOs in litigation. Liability rules can often fail in cases of causal uncertainty or where damage is widespread, reducing the incentives of individual victims to bring a lawsuit, by generating rational apathy. This creates strong arguments in favor of standing for NGOs, particularly in cases of so-called victimless pollution, and in favor of collective or representative actions on behalf of the damaged environment.

Less is known, however, on how ENGOs fulfil this role in practice. We have tried to add to the literature by addressing the role exercised in environmental litigation in France, and by examining a dataset of cases in which environmental damage occurred and then came before the Cour de Cassation in France. The analysis of this dataset shows some interesting features of the role played by ENGOs.

Our empirical results show that ENGOs encourage compliance with regulation, especially for weakly regulated industries, and drive collective action lawsuits that help to solve civil liability failures, especially victims' apathy and full compensation of pure environmental damages. Moreover, their experience in environmental litigation helps them to lower the burden of causal uncertainty, which is often considered as a major failure of civil liability in the domain of environmental accidents. Hence, these findings seem to confirm the assumption in the literature that collective actions exercised by ENGOs can play an important role in providing additional incentives for compliance.

To some extent, our findings may be restricted to the particular case of France, where case law allowed ENGOs also to claim compensation, which in many other European legal systems is only possible under very restrictive conditions.

Although the findings from this paper could provide some information on the way in which ENGOs act in litigation and the effectiveness of their strategies, many questions still remain. One such question refers to the fact that the legal grounds invoked by regular victims are different from those involved by ENGOs. Moreover, our findings seem to indicate that the role played by ENGOs is in line with the literature discussed earlier. However, we obviously did not examine whether the strategies followed by ENGOs are optimal from society's perspective. For example we assumed that ENGOs act in the public (environmental) interest, whereas they may in fact have 
particular interests of their own (e.g. having to do with financing their organization) as well. Moreover, the fact that ENGOs may use the media attention awarded to particular environmental catastrophes to be more successful in lobbying the regulator or winning cases in court should be interpreted with caution, since the results of decisions made under those circumstances are not necessarily the best policy option. This is why one should be careful in using these results at the policy level to conclude that the ENGO activity always leads to positive results. Nevertheless, at least for the particular case of France, the data seem to show that ENGOs have in the past been quite effective in playing a supplementary, gap-filling, role, particularly where ordinary civil liability suits would fail (because of the widespread nature of the damage or causal uncertainty) or where regulatory authorities might insufficiently enforce regulation (due to budget constraints).

Finally, it should be repeated that our study only focused on the role of ENGOs in civil liability litigation. Hence, the conclusions can certainly not be extended to the role of ENGOs in administrative litigation. The question of whether the attitude of ENGOs in administrative litigation would be similar or different is undoubtedly an interesting point for further research.

\section{References}

Abraham K. 2002. The relation between civil liability and environmental regulation: an analytical overview. Washburn Law Journal 4r: 379-398. Backes Chr, Faure M, Fernhout F. 20I4. Legal background. In Access to Justice in Environmental Matters, Faure M, Philipsen N. (eds). Eleven: The Hague.

Baumol W, Oates W. I988. The Theory of Environmental Policy (2nd edn). Cambridge University Press: New York.

Becker G. I983. A theory of competition among pressure groups for political influence. Quarterly Journal of Economics 37I-400.

Ben-Shahar O. 2009. Causation and foreseeability. In Tort Law and Economics, Faure MG (ed.). Elgar: Cheltenham; $83-$ Io8.

Bentata P. 20I3. Environmental regulation and civil liability under causal uncertainty: an empirical study of the French legal system. Review of Law and Economics 9(2): 239-263.

Bentata P. 20I4. Liability as a complement to environmental regulation: an empirical study of the French legal system. Environmental Economics and Policy Studies I6(3): 20I-228.

Bentata P, Faure M. 20I2. The role of environmental civil liability: an economic analysis of the French legal system. Environmental Liability 20(4): I2O-I28.

Billet Ph, Lichère F. 2007. Tort law and regulatory law in France. In Tort and Regulatory Law, van Boom WH, Lukas M, Kissling Chr. (eds). Springer: Vienna; 89-II3.

Binder S, Neumayer E. 2005. Environmental pressure group strength and air pollution: an empirical analysis. Ecological Economics 55: 527-538.

Boré L. 20I0. Action collective et protection de l'environnement. In L'éfficacité du droit de l'environnement. Mise en oeuvre et sanctions, Thèmes et Commentaires, Boskovic O (dir.). Dalloz: Paris; 47-52.

Boutonnet M. 20I0. L'arrêt Erika, vers la réparation intégrale des préjudices résultant des atteintes à l'environnement? Environnement No 7: Étude I4.

Buchanan J, Stubblebine C. I962. Externality. Economica 29: 37I-384.

Carbonnier J. 2004. Droit Civil. Tome 2: les biens, les obligations. Presses Universitaires de France: Paris.

Coase RH. I960. The problem of social cost. Journal of Law and Economics 3: I-43.

Damania R, Fredriksson P, Gates S, Neumayer E. 2005. Environmentalism, democracy, and pollution control. Journal of Environmental Economics and Management 49(2): 343-365.

Dari-Mattiacci G, Deffains B, Lovat B. 20II. The dynamics of legal system. Journal of Economic Behavior and Organization 79: 95-I07.

De Geest G, Dari-Mattiacci G. 2003. On the Intrinsic Superiority of Regulation and Insurance over Tort Law, working paper, Utrecht University.

Deffains B, Doriat-Duban M, Langlais E. 2008. Economie des actions collectives. Puf: Paris.

Deffains B, Langlais E. 20I2. A case for information sharing in class action suits. In The Law and Economics of Class Actions in Europe, Backhaus GJ, Cassone A, Ramello GB. (eds). Elgar: Cheltenham.

Dewees D, Duff D, Trebilcock M. I996. Exploring the Domain of Accident Law Taking the Facts Seriously. Oxford University Press: Oxford.

Faure MG. 2007a. Economic analysis of tort and regulatory law. In Tort Law and Regulatory Law, van Boom WH, Lukas M, Kissling C. (eds). Vienna: Springer; 4IO-4I5.

Faure MG. 2007b. L'analyse économique du droit de l'environnement. Bruylant.

Faure MG, Betlem G. 2008. Applying national liability law to transboundary pollution: some lessons from Europe and the United States. In China and International Environmental Liability. Legal Remedies for Transboundary Pollution, Faure MG, Song Y. (eds). Elgar: Cheltenham; I67-I69.

Faure MG, Escresa L. 20Iı. Social stigma. In Production of Legal Rules, F. Parisi (ed.). Elgar: Cheltenham; $205-227$.

Faure MG, Van den Bergh R. I990. Liability for nuclear accidents in Belgium from an interest group perspective. International Review of Law and Economics IO(3): 24I-254. 
Fredriksson P. I997. The political economy of pollution taxes in a small open economy. Journal of Environmental Economics and Management 33: $44-58$.

Harford J, Harrington W. I99I. A reconsideration of enforcement leverage when penalties are restricted. Journal of Public Economics 45: 39I-395. Harrington W. I988. Enforcement leverage when penalties are restricted. Journal of Public Economics 37: $29-53$.

Keenan D, Rubin P. I988. Shadow interest groups and safety regulation. International Review of Law and Economics 8(I): 2I-36.

Keske S, Renda A, Van den Bergh R. 20I0. Financing and group litigation. In New Trends in Financing Civil Litigation in Europe, a Legal, Empirical and Economic Analysis, Tuil M, Visscher L. (eds). Elgar: Cheltenham; 57-9I.

Liu J. 20I3. Compensating Ecological Damage. Comparative and Economic Observations. Intersentia: Antwerp.

Nowell C, Shogren JF. I99I. Challenging the Enforcement of Environmental Regulation, Center for Agricultural and Rural Development. Working Paper 9I-WP 80.

Ogus A. 2004. Regulation: Legal Form and Economic Theory. Hart.

Olson M. I994. The Logic of Collective Action: Public Goods and the Theory of Groups (I5th edn). Harvard University Press: Cambridge.

Prieur M. 20II. Droit de l'environnement (6th edn), Collection. Dalloz: Paris.

Quirion P. 1999. Le marché de l'assurance du risque pollution en France. Ministère de l'Aménagement du Territoire et de l'Environnement, DGAD-SRAE. CERNA, Ecole des Mines: Paris.

Richardson G, Burrows P, Ogus AI. I982. Policing Pollution: a Study of Regulation and Enforcement. Clarendon: Oxford.

Rose-Ackerman S. I99I. Regulation and the law of torts. American Economic Review 8I(2): 54-58.

Schäfer H-B. 2000. The bundling of similar interests in litigation. The incentives for class actions and legal actions taken by associations. European Journal of Law and Economics 9(3): 183-213.

Shavell S. I984. A model of the optimal use of liability and safety regulation. Rand Journal of Economics I5: 27I-280.

Shavell S. 1986. The judgement proof problem. International Review of Law and Economics 6: 45-58.

Sintez C. 20II. La sanction préventive en droit de la responsabilité civile, Nouvelle Bibliothèque de Thèses. Dalloz: Paris.

Smith G, Connelly J. I999. Politics and the Environment. Routledge: London.

Stigler GJ. I97I. The theory of economic regulation. Bell Journal of Economics 2: 359-365.

Viger S. 2000. Pollution de l'environnement: risques et responsabilités. Démos.

Viney G. 2006. L'action d'intérêt collectif et le droit de l'environnement. In Les responsabilités environnementales dans l'espace européen. Point de vue franco-belge, Viney G, Dubuisson B. (eds). Bruylant: Brussels; 2I7-242.

Viney G, Jourdain P. 200I. Les effets de la responsabilité. Librairie Générale de Droit et de Jurisprudence: Paris.

Viscusi WK. 2006. Regulation of Health, Safety and Environmental Risks, NBER Working Paper II934.

Viscusi WK, Harrington JE, Vernon JM. I995. Economics of Regulation and Antitrust. MIT Press. 